\title{
Molecular detection of Treponema pallidum sp. pallidum in blood samples of VDRL-seroreactive women with lethal pregnancy outcomes: A retrospective observational study in Northern Brazil
}

\author{
Detecção molecular do Treponema pallidum sp. pallidum em amostras de sangue de mulheres \\ sororeativas ao VDRL com resultado letal da gravidez: Um estudo observacional retrospectivo \\ no norte do Brasil
}

\section{Charliana Aragão Damasceno Casal ${ }^{1}$, Mayra Oliveira da Silva ${ }^{1}$, Igor Brasil Costa ${ }^{1}$, Eliete da Cunha Araújo ${ }^{2}$ and Tereza Cristina de Oliveira Corvelo ${ }^{1,3}$}

\begin{abstract}
Introduction: Although control measures of maternal and congenital syphilis are available in Brazil, difficulties exist within the healthcare network in providing a laboratory diagnosis of the infection during the prenatal period. The objective of this study was to confirm the presence of Treponema pallidum by PCR in women with positive VDRL serology and lethal pregnancy outcomes, i.e., abortion, stillbirth and neonatal death. Methods: A retrospective study was conducted on VDRLseroreactive women with lethal pregnancy outcomes admitted to the Fundação Santa Casa de Misericórdia do Pará (FSCM-PA) between January and July 2004. Serum samples and DNA from whole blood were obtained at the time of screening by the VDRL test. These samples were analyzed by IgG ELISA, IgM FTA-Abs and simple PCR (polA). Results: During the study period, 0.7\% $(36 / 4,912)$ of women with lethal pregnancy outcomes presented a positive VDRL test. The polA gene was amplified in $72.7 \%(24 / 33)$ of these women, with $55.6 \%(20 / 36)$ and $94.4 \%(34 / 36)$ presenting $\operatorname{IgM}$ and $\operatorname{IgG}$ antibodies against T. pallidum, respectively. Comparison of these results showed a significant difference, with agreement between the PCR and IgM FTA-Abs results, suggesting that maternal syphilis was an active infection. No basic cause of death of the conceptus was reported in $97.2 \%(35 / 36)$ of cases. Among women who were submitted to the VDRL test during the prenatal period, only four of the nine seroreactive patients underwent treatment. Conclusions: The high frequency of syphilis in the group studied indicates the fragility of the service of infection diagnosis, treatment and monitoring, compromising epidemiological control. Keywords: Syphilis. Lethal pregnancy outcomes. PCR. VDRL.
\end{abstract}

\section{RESUMO}

Introdução: Apesar das medidas de controle da sífilis materna e congênita estarem disponíveis no Brasil, existem dificuldades da rede em prover o diagnóstico laboratorial da infecção durante o pré-natal. O objetivo deste estudo foi confirmar a presença do Treponema pallidum pela PCR em mulheres com sorologia positiva ao VDRL e com resultado letal da gravidez, isto é, aborto, natimorto e neomorto. Métodos: Estudo retrospectivo realizado em mulheres VDRL-sororeativas com resultado negativo da gravidez, admitidas na Fundação Santa Casa de Misericórdia do Pará FSCM-PA entre janeiro e julho de 2004. As amostras de soro e DNA de sangue total foram obtidas no mesmo período da triagem pelo VDRL. Estas amostras foram analisadas pelo ELISA IgG, FTAAbs IgM e PCR simples (polA). Resultados: Durante o período de estudo, 0,7\% (36/4.912) das mulheres com resultado letal da gravidez apresentaram VDRL positivo. O gene polA foi amplificado em $72,7 \%$ (24/33) destas mulheres, com 55,6\% (20/36) e 94,4\% (34/36) apresentando anticorpos tipo IgG e IgM contra o T. pallidum, respectivamente. A comparação destes resultados mostrou uma diferença estatística significativa, sendo que os resultados da PCR versus FTA-Abs IgM mostraram-se concordantes, sugerindo que a sífilis materna era uma infecção ativa. A causa básica de morte dos conceptos não foi relatada em $97,2 \%(35 / 36)$ dos casos. Entre as mulheres que foram submetidas ao VDRL no pré-natal, somente quatro das nove soropositivas receberam tratamento. Conclusões: A elevada frequência de sífilis no grupo de estudo indica a fragilidade do serviço no diagnóstico, tratamento e monitoramento da infecção, comprometendo o controle epidemiológico. Palavras-chaves: Sífilis. Resultado letal da gravidez. PCR. VDRL.

1. Laboratório de Imunogenética, Universidade Federal do Pará, Belém, PA. 2. Faculdade de Medicina, Universidade Federal do Pará, Belém, PA. 3. Núcleo de Medicina Tropical, Universidade Federal do Pará, Belém, PA.

Address to: Dra. Charliana Aragão Damasceno Casal. ICB/Lab. Imunogenética/UFPA. Av. Augusto Correa 01, Bairro Guamá, 66075-110 Belém, PA, Brasil.

Phone: 5591 3241-0032; Fax: 5591 3201-8430

e-mail: charliana@gmail.com

Received in 14/01/2011

Accepted in 17/02/2011

\section{INTRODUCTION}

Syphilis is a sexually transmitted disease (STD) caused by Treponema pallidum subspecies pallidum, with an estimated 12 million new cases per year ${ }^{1}$. In Brazil, studies have shown a prevalence of syphilis of $1.6 \%$ among pregnant women ${ }^{2}$. According to data from the Ministry of Health ${ }^{3}$, 46,530 cases of congenital syphilis (CS) were notified in infants younger than one year-old between 1998 and 2008, and approximately 1,189 deaths due to CS were reported, with an incidence of $9 \%$ in the Northern region. Notification of CS has been compulsory in Brazil since $1986^{2}$; however, only after 2005 were suspected or confirmed cases of syphilis in pregnant women included in this register, because of their epidemiological importance ${ }^{3}$.

The consequences of undiagnosed and/or inadequately treated syphilis during the prenatal period include abortion, stillbirth, premature birth, newborns with clinical signs of CS and, more frequently, apparently healthy children who later develop clinical signs $^{2,4-7}$. Approximately $40 \%$ of pregnancies with maternal-fetal transmission result in spontaneous abortion, stillbirth, and perinatal death $\mathrm{h}^{2,5,6,8}$.

Some factors related to maternal infection increase the probability of CS, including the presence of primary syphilis or syphilis of indeterminate duration, high titers in nontreponemal tests (VDRL or $\mathrm{RPR} \geq 1: 16$ ) during treatment or delivery, inadequate prenatal care (few or no prenatal visits), a short time interval between treatment and birth $(<4$ weeks), untreated syphilis and untreated partners ${ }^{2,4,6,8}$. Maternal and congenital syphilis continue to be important causes of stillbirth and infant morbidity and mortality worldwide ${ }^{9,10}$.

Between 0.5 and 1 million of cases of CS occur worldwide every year and more than $1 / 5$ of cases of neonatal mortality are directly attributed to syphilis 
in some developing countries ${ }^{2,4,9,10}$. The presumptive diagnosis of syphilis is made indirectly by nontreponemal serological tests, such as Venereal Disease Research Laboratory (VDRL) and rapid plasma reagin (RPR), and treponemal tests, such as fluorescent treponemal antibody absorption (FTA-Abs) and Treponema palidum hemagglutination assay (TPHA). Nontreponemal tests are used for screening and may yield false-positive results. Thus, treponemal tests are performed to confirm the screening tests when disease is suspected ${ }^{2,8}$. In addition, T. pallidum cannot be grown in culture, so a definitive diagnosis is made by direct visualization of the spirochete under a dark-field microscope or by direct fluorescent antibody testing. Both methods require skilled personnel and are not widely available ${ }^{8}$.

Polymerase chain reaction (PCR) could be an interesting alternative for diagnosing syphilis in the mother and contributing to rapid identification of the disease (primary, secondary and latent syphilis $)^{11-15}$, which can lead to adverse pregnancy outcomes with deleterious effects on the newborn when not diagnosed and treated adequately. In addition, studies of this approach have shown that it is a valuable tool and may contribute to epidemiological control of maternal and congenital syphilis in Brazil, reducing government expenditure on preventable and curable diseases.

The objective of the present study was to confirm the presence of T. pallidum by PCR in whole blood of VDRL-seroreactive women with lethal pregnancy outcomes admitted to a referral hospital for maternal-fetal medicine in Northern Brazil.

\section{METHODS}

\section{Settings}

A retrospective study was conducted on 4,912 women admitted for delivery or curettage to the obstetric center of Fundação Santa Casa de Misericórdia do Pará (FSCM-PA), Brazil, between January and July 2004. In this study, a cohort of 36 women with lethal pregnancy outcomes and seroreactive in the VDRL screening test for syphilis were investigated, who were diagnosed while receiving hospital care during the period mentioned. Other cases of pregnancies with lethal outcomes reported in the hospital were excluded from the study, since they were associated with causes not related to the study, such as provoked abortion, congenital malformation and chromosome anomalies, among others. For all pregnancies, spontaneous abortion, stillbirth or neonatal death of the conceptus was defined as a lethal outcome.

Data regarding personal identification, sexual/reproductive health and obstetric history were obtained using a standard protocol applied to the women during the period studied. The patient records were reviewed for clinical diagnosis and the cause of fetal and neonatal death.

\section{Biological specimens and serology}

Samples of whole blood collected with ethylenediaminetetraacetic acid (EDTA) as anticoagulant and serum were obtained and processed at the time of screening by the VDRL test (January and July 2004). The serum samples were analyzed in duplicate using the IgG Treponema pallidum ELISA kit (Novatec Immunodiagnostica $\mathrm{GmbH}$, Dietzenbach, Germany) and Imuno-Con IgM FTA-Abs kits (Wama Diagnóstica, São Carlos, SP, Brazil) for confirmation of the VDRL test result. Each test was performed in accordance with manufacturer's recommendations.
Whole DNA was extracted from blood using the phenolchloroform method during the same period and stored at $-70^{\circ} \mathrm{C}$ for one year at the Laboratory of Immunogenetics, Federal University of Pará, and periodically shipped for PCR.

\section{DNA extraction and PCR}

DNA was extracted from whole blood using the phenolchloroform method. For this, $300 \mu \mathrm{L}$ of whole blood obtained from each patient was mixed with $1 \mathrm{ml}$ red blood cell lysis solution [solution A (100mL): $1 \mathrm{M} \mathrm{NH}_{4} \mathrm{Cl}, 1 \mathrm{MEDTA}$; solution B $(5.58 \mathrm{~mL})$ : $\left.1 \mathrm{M} \mathrm{NH}_{4} \mathrm{HCO}_{3}\right]$. The mixture was homogenized by perpendicular shaking for $15 \mathrm{~min}$ and centrifuged at $20,000 \mathrm{xg}$ for $5 \mathrm{~min}$, after which the supernatant was carefully discarded. This procedure was repeated an additional two times. Next, $10 \mu \mathrm{l}$ proteinase $\mathrm{K}$ and $300 \mu \mathrm{l}$ alkaline lysis buffer (100mmol/L Tris-HCl, 20mmol/L EDTA, 200mmol/L $\mathrm{NaCl}, 1 \%$ dodecyl-sodium sulfate, $0.2 \% \beta$-mercaptoethanol) were added to the lysate and the mixture was incubated for $12 \mathrm{~h}$ at $58^{\circ} \mathrm{C}$. The lysate was extracted with an equal volume of phenolchloroform, precipitated with isopropano, and washed with $70 \%$ alcohol. The pellet was resuspended in $200 \mu \mathrm{L}$ of sterile distilled water. The concentration and integrity of the DNA were measured by spectrophotometry $(\mathrm{A} 260 \mathrm{~nm} / 280 \mathrm{~nm})$ and amplification of the universal $16 \mathrm{~S}$ ribosomal gene ${ }^{16}$, respectively.

The samples were analyzed by simple PCR targeting the polymerase I (polA) gene of T.pallidum. The following primers were used based on a 209-bp region of the polA gene that is unique to T. pallidum: a $22 \mathrm{mer}-$ forward primer (5'-AGACGGCTGCACATCTTCTCCA-3') and a 22-mer reverse primer (5'AGCAGACGTTACATCGAGCGGA-3'). The PCR mixture contained $0.02 \mathrm{mM}$ of each dNTP, 1X PCR buffer, $0.18 \mathrm{mM} \mathrm{MgCl}_{2}, 1.0$ unit Taq DNA Platinum Polymerase (Invitrogen, São Paulo, Brazil), and $5 \mu$ l of the DNA sample, adjusted to a final volume of $25 \mu \mathrm{L}$ with sterile water. T. pallidum Nichols strain, kindly provided by Dr. Hsi Liu from the Centers for Disease Control and Prevention (CDC, Atlanta, Georgia), was used as positive control. DNA from one control sample (VDRL/ELISA IgG-seronegative) and PCR mixture without DNA were used as negative controls. PCR was performed in an Eppendorf Mastercycler under the following conditions: $94^{\circ} \mathrm{C}$ for $3 \mathrm{~min}, 60^{\circ} \mathrm{C}$ for $30 \mathrm{~s}$, and $72^{\circ} \mathrm{C}$ for $45 \mathrm{~s}$ (40 cycles). After the final cycle, the mixture was incubated at $72^{\circ} \mathrm{C}$ for $7 \mathrm{~min}$ to complete the reaction. The PCR products were separated by electrophoresis on $1.5 \%$ agarose gel stained with ethidium bromide for visualization of the amplicon.

\section{Statistical analysis}

Pearson's linear correlation test was applied to evaluate the correlation between the concentration of treponemal (IgG ELISA) and nontreponemal (VDRL) antibodies. For this analysis, anti-cardiolipin antibody titers were submitted to reciprocal transformation. The contingency coefficient $\mathrm{C}$ test was used to evaluate the association between VDRL results versus IgM FTAAbs. A pooled proportion test ( $\mathrm{p}$ value combined $_{\text {) was also calculated }}$ to compare with the results of T. pallidum diagnostic methods, including IgG ELISA, IgM FTA-Abs, and PCR. Statistical analysis was performed using the Bioestat 5.0 software ${ }^{17}$. Differences were considered to be statistically significant when $\mathrm{p}$ values were less than 0.05 .

\section{Ethical considerations}

The study was approved by the Research Ethics Committee of the Nucleus of Tropical Medicine, Federal University of Pará, Brazil. 


\section{RESULTS}

According to the records of FSCM-PA, 3,809 deliveries were performed between January and July 2004, including $62 \%$ $(2,365 / 3,809)$ normal deliveries and $38 \%(1,444 / 3,809)$ cesarean sections. Live births accounted for $94.6 \%(\mathrm{n}=3,602)$ of all 3,809 deliveries and stillbirths corresponded to $5.4 \%(\mathrm{n}=207)$. In addition, there were 1,103 cases of uterine curettage due to spontaneous abortion.

During the study period, $36(0.7 \%)$ of 4,912 delivery and curettage cases were women with a positive VDRL screening test for syphilis who presented a negative pregnancy outcome. Stillbirth was observed in $52.8 \%$ (19/36) of these women, neonatal death in $19.4 \%$ (7/36), and abortion in $27.8 \%(10 / 36)$. The adverse pregnancy outcome occurred between 23 and 41 weeks of gestation in $66.7 \%$ $(24 / 26)$ of the patients. All women were multiparous, with $25 \%$ (9/36) of them reporting a history of abortion.

Table 1 shows some of the characteristics of sexual/reproductive health and prenatal care of the patients with syphilis and lethal pregnancy outcome. The mean age was $21.8 \pm 4.5$ years-old. Regarding prenatal care, $36.1 \%(13 / 36)$ of the women did not attend any prenatal visit. Among the women attending at least one prenatal visit, $65.2 \%(15 / 23)$ were submitted to the VDRL test and only $26.7 \%(4 / 15)$ underwent another VDRL screening test. However, only four of the nine patients who tested positive during this period received treatment with benzathine penicillin $G$ (a dose of 2.4 million units) and only one of the partners was also treated. The other seroreactive patients were not submitted to antibiotic therapy.

Regarding sexual/reproductive health, $58.3 \%(21 / 36)$ of the patients reported a clinical-laboratory diagnosis of STDs, including syphilis in 44.4\% (16/36), gonorrhea in 5.5\% (2/36), HIV infection and syphilis in 20\% (2/36), and herpes/syphilis in $2.8 \%(1 / 36)$. In addition, $83.3 \%$ (30/36) of the women did not use preservatives and $69.4 \%(25 / 36)$ reported sexual contact with two or more partners over the preceding 18 months.

A review of the patient records showed that two patients were HIV seropositive, seven were seronegative and no HIV result was reported in 27. Regarding the clinical characteristics of syphilis, only $11.1 \%(4 / 36)$ of the women reported symptoms during pregnancy, including hard chancre in one and syphilitic roseolae in three.
TABLE 1 - Characteristics of the 36 women with lethal pregnancy outcomes seen at FSCM-PA between January and July 2004.

\begin{tabular}{|c|c|c|}
\hline Characteristic & Number & Percentage \\
\hline \multicolumn{3}{|c|}{ History of other STDs $(n=36)$} \\
\hline yes & 21 & 58.3 \\
\hline no & 15 & 41.7 \\
\hline \multicolumn{3}{|l|}{ Use of preservatives $(n=36)$} \\
\hline yes & 6 & 16.7 \\
\hline no & 30 & 83.3 \\
\hline \multicolumn{3}{|c|}{ Number of sex partners over the last 1.5 years $(n=36)$} \\
\hline 1 partner & 11 & 30.6 \\
\hline$\geq 2$ partners & 25 & 69.4 \\
\hline \multicolumn{3}{|l|}{ Prenatal care $(n=36)$} \\
\hline yes* & 23 & 63.9 \\
\hline no & 13 & 36.1 \\
\hline \multicolumn{3}{|c|}{ VDRL test during prenatal period $(n=23)$} \\
\hline yes & 15 & 65.2 \\
\hline no & 8 & 34.8 \\
\hline \multicolumn{3}{|c|}{ VDRL result/prenatal treatment $(n=15)$} \\
\hline reactive/treated ${ }^{* *}$ & 4 & 26.7 \\
\hline reactive/not treated ${ }^{* * *}$ & 5 & 33.3 \\
\hline non-reactive & 6 & 40.0 \\
\hline Age, years (mean $\pm S D)$ & \multicolumn{2}{|c|}{$21.8 \pm 4.5$} \\
\hline
\end{tabular}

FSCM-PA: Fundação Santa Casa de Misericórdia do Pará, STDs: Sexually transmitted disease.

VDRL: Venereal Disease Research Laboratory, SD:Standard deviation.

${ }^{*}$ at least two visits, ${ }^{* *}$ patient underwent treatment recommended by the physician, ${ }^{* *}$ patient did not undergo treatment recommended by the physician.

The distribution of VDRL titers and the results of IgG ELISA, IgM FTA-Abs and PCR obtained for the patients studied are shown in Table 2. Statistical analysis revealed a positive correlation only between treponemal (ELISA IgG) and nontreponemal (VDRL) serological tests, i.e., the concentration of anti-cardiolipin antibodies increased with increasing concentration of $\operatorname{IgG}$ antibodies against T. pallidum.

Concerning the molecular diagnosis, three DNA samples were excluded from the PCR analysis because these samples presented low concentrations by spectrophotometry and negative PCR for the 16S RNA gene. T. pallidum DNA was not identified in the negative control with DNA template from VDRL/ELISA IgG-negative blood samples. Thus, the polA (Figure 1) gene was amplified by PCR in

TABLE 2 - Distribution of the VDRL, IgG ELISA, IgM FTA-Abs and PCR results in women with syphilis.

\begin{tabular}{|c|c|c|c|c|c|c|c|c|c|c|c|c|c|c|}
\hline \multirow[b]{2}{*}{ Titer } & & & \multicolumn{4}{|c|}{ IgG ELISA $(n=36)$} & \multicolumn{4}{|c|}{ IgM FTA-Abs $(n=36)$} & \multicolumn{4}{|c|}{ PCR PolA $(+)(n=33)$} \\
\hline & $\mathrm{n}$ & $\%$ & $\mathrm{n}$ & $\%$ & $\mathrm{n}$ & $\%$ & $\mathrm{n}$ & $\%$ & $\mathrm{n}$ & $\%$ & $\mathrm{n}$ & $\%$ & $\mathrm{n}$ & $\%$ \\
\hline $1: 2$ & 3 & 8.3 & 3 & 8.3 & - & - & 1 & 2.8 & 2 & 5.6 & 1 & 3.0 & 2 & 6.1 \\
\hline $1: 4$ & 2 & 5.5 & 2 & 5.5 & - & - & 1 & 2.8 & 1 & 2.8 & 2 & 6.1 & - & - \\
\hline $1: 32$ & 10 & 27.7 & 10 & 27.8 & - & - & 7 & 19.4 & 3 & 8.3 & 6 & 18.2 & 3 & 9.1 \\
\hline $1: 64$ & 6 & 16.6 & 6 & 16.7 & - & - & 2 & 5.6 & 4 & 11.1 & 3 & 9.1 & 2 & 6.1 \\
\hline $1: 128$ & 4 & 11.1 & 4 & 11.1 & - & - & 4 & 11.1 & - & - & 4 & 12.1 & - & - \\
\hline Total & 36 & 100.0 & 34 & 94.4 & 2 & 5.6 & 20 & 55.6 & 16 & 44.4 & 24 & 72.7 & 9 & 27.3 \\
\hline
\end{tabular}

VDRL: Venereal Disease Research Laboratory, IgM: G Immunoglobulin, ELISA: Enzyme-Linked Immunosorbent Assay, PCR: Polymerase chain reaction, IgG: G Immunoglobulin, FTA-Abs: fluorescent treponemal antibody absorption, PolA: Polymerase I. 


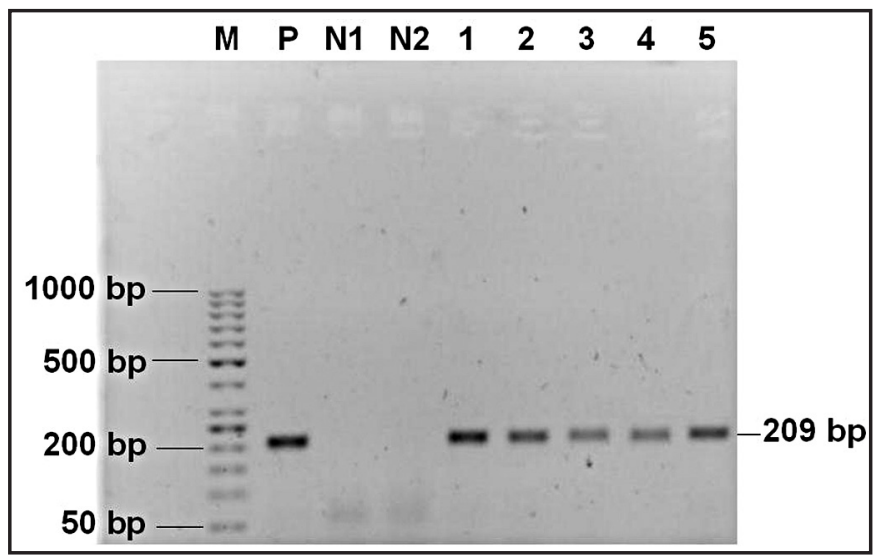

FIGURE 1 - Amplification of the polA gene (209bp) of Treponema pallidum.

Panels 1-5: patient specimens, M: molecular marker (100bp); P: positive control; $\mathrm{N} 1$ and N2: negative controls.

$72.7 \%(24 / 33)$ of samples, i.e., in $80 \%(8 / 10)$ of the women who had a spontaneous abortion, in $57.9 \%(11 / 19)$ of those whose child was stillborn, and in $71.4 \%$ (5/7) of those whose child was born alive and died after delivery.

Comparison of these PCR results with the results of ELISA IgG and FTA-Abs IgM showed a significant difference ( $\left.\mathrm{p}_{\text {combined }}=0.0008\right)$, with the observation of different proportions between ELISA versus PCR $(p<0.05)$ and ELISA versus FTA-Abs $(p<0.01)$. ELISA detected a larger number of cases of syphilis; however, the results of PCR and FTA-Abs were similar ( $\mathrm{p}>0.05)$.

Some discordant results were observed when comparing the serological tests and PCR as follows: group I: one woman who presented a positive molecular test, a seronegative IgG ELISA/IgM FTA-Abs and VDRL titers of 1:8 was asymptomatic and had no history of syphilis. The patient was admitted for abortion during the first trimester of gestation and attended no prenatal visit. Group II: five women who tested negative by PCR were seroreactive by ELISA/ FTA-Abs, three with VDRL titers $\geq 1: 32$ and two with titers $\leq 1: 8$ had a history of syphilis infection. Two of them had HIV/syphilis.

Regarding the cause of death of the conceptus of patients with suspected syphilis, the basic cause of death was not reported in $97.2 \%$ $(35 / 36)$ of cases and was classified as unknown or indeterminate on the death certificate. The basic cause of death was only reported in the case of one conceptus (neonatal death), i.e., prematurity associated with cardiorespiratory arrest. In the stillbirth group, intrauterine anoxia and amniorrhexis/chorioamnionitis were reported as a secondary cause of death in $21 \%(4 / 19)$ and $5.3 \%(1 / 19)$ of the death certificates, respectively.

Regarding prenatal treatment, four patients who were diagnosed and treated for primary syphilis were positive by PCR, IgG ELISA and IgM FTA-Abs at the time of admission for delivery or curettage, with three presenting titers $\geq 1: 32$ and one titers of $1: 4$ during this period. These patients were at 24 to 32 weeks of gestation and the lethal outcome was stillbirth. In addition, four of the five VDRLseroreactive patients not treated during the prenatal period tested positive by PCR/IgG ELISA, with titers 1:32. Two of these patients were positive by IgM FTA-Abs (Table 1).

\section{DISCUSSION}

T. pallidum DNA was amplified in approximately $72 \%$ of the whole blood samples from VDRL-seropositive and IgM FTA-Absseropositive women, suggesting that maternal syphilis is an active infection. In addition, the polA gene was detected in $68.7 \%$ of the patients with FTA-Abs (-) /ELISA (+).

Previous studies have confirmed the presence of T. pallidum in peripheral blood by molecular biology methods, with a sensitivity of $\geq 10$ spirochetes in samples ${ }^{6,8,11-14}$. The polymerase I gene has been preferentially used for screening suspected cases of syphilis ${ }^{11-15,18}$. Studies using different target genes and different combinations of treponemal and nontreponemal serological methods verified a good correlation between PCR and serology results, ranging from 88 to $96 \%{ }^{19-21}$. Marfin et $\mathrm{al}^{13}$ detected the polA gene in whole blood samples of $64 \%$ (9/14) of individuals with a reactive MHA-TP and of $43 \%$ (6/14) of individuals with RPR titers of 1:8 or higher.

The present study verified a strong significant association between the results obtained by PCR and IgM FTA-Abs, supporting the consideration of a recent infection. Leslie et $\mathrm{al}^{22}$ reported $95 \%$ agreement between PCR and the combined serology results (RPR/ TPPA/EIA IgM-IgG/EIA IgM) in the investigation of recent syphilis. In contrast, our group observed a difference in the proportions of the results of IgM FTA-Abs versus IgG ELISA and PCR versus IgG ELISA that may be attributed to the low sensitivity of PCR and FTA-Abs. However, it should be emphasized that most patients were clinically diagnosed with indeterminate syphilis and that 19 women of this group reported treatment for syphilis prior to the pregnancy studied, which could be related to the serological detection of antibodies of a previous infection ${ }^{5,8,23,24}$, or to a small number of treponemes in the circulation $8,22,25$.

In the present study, statistical analysis between treponemal and nontreponemal serological tests showed a significant correlation between the magnitude of treponemal (IgG ELISA) and nontreponemal (VDRL) antibody titers, confirming the diagnostic value of VDRL in maternal syphilis. However, the sensitivity of the VDRL test has been shown to be lower during the early and late stages of the disease $\mathrm{e}^{2,4,8,23,25-27}$, a fact that may explain the negative results obtained for $34.8 \%$ of the women during prenatal care, since they were submitted to only one VDRL test and none were submitted to a treponemal test during the prenatal period.

Studies have shown high sensitivity for the treponemal tests ELISA, FTA-Abs and TPHA during the early and late stages of infection $^{4,5,8,25-27}$. Thus, the combination of nontreponemal and treponemal tests during prenatal screening and on admission to delivery is important, since it contributes to both the exclusion of a false-positive result ${ }^{26}$ and the detection of a false-negative VDRL ${ }^{28,29}$, taking into account the limitations of the latter. A study conducted in South Africa ${ }^{26}$, where syphilis is a significant cause of adverse pregnancy outcomes, showed that the use of both a nontreponemal and a treponemal test was important for prenatal screening, since these tests reduced adverse pregnancy outcomes by permitting an accurate diagnosis, immediate treatment and monitoring of the infection.

Concerning the discrepant results observed, we speculate that the case in group I presenting positive PCR and negative specific treponemal serology could represent a very recent infection with low pathogen levels that may not be sufficient to induce the production 
of specific IgM/IgG antibodies ${ }^{22,30}$. Palmer et $\mathrm{al}^{19}$ attributed this type of discrepancy to patients with immune dysfunction associated with antibiotic treatment that may have blunted a serological response to T. pallidum. On the other hand, the possibility of a false-positive PCR result cannot be ruled out.

Regarding group II, the discordant results between PCR and the serological tests could be related to the following factors: A) nonspecific serological reactions due to HIV/syphilis coinfection, especially since the women presented low ELISA, FTA-Abs and VDRL titers and had a history of treatment for syphilis ${ }^{25}$; B) low titers for antitreponemal ( $\operatorname{IgG}) /$ nontreponemal (cardiolipin) antibodies are expected to persist for a long period of time in patients following cure $^{4,23,25}$; and/or C) the sensitivity of the polA-PCR technique in detecting T. pallidum DNA in blood sample could have been low. Several studies have attributed the low sensitivity in detecting $T$. pallidum to the PCR method used, the choice of primer and the type of sample selected ${ }^{13,18,19,31}$. While evaluating three PCR assays using different biological specimens, Castro et $\mathrm{l}^{31}$ verified that the 47-PCR test was the most sensitive (39.1\%) for detecting T. pallidum DNA in latent syphilis, followed by M-PCR (38.3\%) and PolA-PCR (31.1\%). In addition, the best results were obtained with ear lobe scrapings, followed by plasma, whole blood and sera.

In the present study, certain risk factors for sexually transmitted infections (STIs) were observed, i.e., the majority of the women did not use preservatives, had sexual relations with two or more partners during the preceding 18 months and had a history of STIs (laboratory diagnosis of syphilis, syphilis/HIV, gonorrhea and Chlamydia). Several reports have emphasized the epidemiological importance of these variables as risk factors for STIs ${ }^{1,432-34}$. It is important to emphasize that some factors related to maternal infection increase the probability of CS, including the presence of primary syphilis or syphilis of indeterminate duration, high titers in nontreponemal tests during treatment or delivery, inadequate prenatal care, a short time interval between treatment and birth ( $<4$ weeks), untreated syphilis and untreated partners ${ }^{2,4,6,8}$.

More than $25 \%$ of the women studied did not attend prenatal care. In addition, many of the women who attended prenatal visits were not screened for syphilis infection. Among the women who were submitted to the VDRL test, more than $60 \%$ were seroreactive, but less than half were treated for the infection. None of the women submitted to the VDRL test during the prenatal period were submitted to a treponemal test.

The polA gene was detected even in women who were diagnosed and treated during the prenatal period. These women were also positive by IgM FTA-Abs and IgG ELISA and presented high anti-cardiolipin antibody titers at the time of the lethal outcome, demonstrating that the prenatal care offered was ineffective in preventing adverse pregnancy outcomes. These findings reflect the low compliance with prenatal follow-up and the failure of the service to diagnose and monitor treatment, which should be established for both the pregnant woman and her partner. Increasing prenatal coverage and providing access to prenatal services have proven to be good strategies, with a positive impact on the reduction of cases of maternal and congenital syphilis and the transmission of HIV ${ }^{34-36}$.

The cause of death was not determined in the cases of stillbirth or neonatal death; the death certificates did not state any cause of death. In Brazil, the poor quality of death records is one of the main limiting factors of the investigation and analysis of mortality profiles, especially in socioeconomically less developed regions, such as the north and northeast ${ }^{32,37}$. In addition, the cause of lethal pregnancy outcome is determined by autopsy of the fetus, a procedure that is not always performed in Brazil and is often not possible to perform ${ }^{32}$. This fact impairs the determination of the true magnitude of CS as a cause of fetal and neonatal death.

The high agreement between the results of PCR and IgM FTA-Abs in the women with lethal pregnancy outcome does not rule out the possibility that maternal infection caused the death

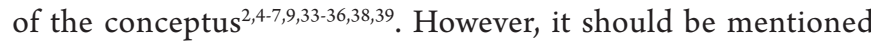
that biological material for the analysis of congenital infection and consequent confirmation of the relation of maternal/fetal syphilis with the lethal outcome could not be obtained during the development of the study protocol, thus further studies are necessary.

Several limitations warrant discussion, the main one is the lack of a gold standard for the direct detection of T. pallidum with which to compare the PCR assay. The gold standard for diagnosis of syphilis is the rabbit infectivity test (RIT), in which the body fluid with suspected syphilis is injected into a rabbit. This test has proven high sensitivity and is able to detect a single viable organism in the sample , $^{8}$ but it is not used routinely in clinical practice in Brazil and requires special conditions for its execution. However, previous studies have demonstrated a correlation between PCR amplification and RIT for whole blood ${ }^{40,41}$.

Finally, PCR could be an interesting alternative for the diagnosis of syphilis in the mother, which would contribute to rapid identification of the disease and to epidemiological surveillance of syphilis, which is a serious public health problem in Brazil. Prenatal care with a good coverage rate and effective clinical-laboratory monitoring are fundamental measures for minimizing maternal-fetal syphilis transmission and, consequently, reducing adverse pregnancy outcomes.

High agreement between the results of PCR and IgM FTA-Abs in VDRL-seropositive women with lethal pregnancy outcome indicates active infection with T. pallidum. This situation associated with the lack of diagnostic monitoring and adequate treatment during the prenatal period suggests the need to investigate maternal-fetal syphilis and cases of death of the conceptus of women with syphilis, using more sensitive and specific diagnostic methods. Within this context, PCR could contribute to epidemiological surveillance of syphilis, especially CS, in which laboratory diagnosis is more difficult, and promote actions for the surveillance and control of the disease.

\section{ACKNOWLEDGMENTS}

The authors are grateful to all persons who participated in the study. We especially thank Dr. Hsi Liu (CDC, Atlanta) for kindly providing the T. pallidum control strain. Written consent for publication was obtained from the patients or their relatives.

\section{CONFLICT OF INTEREST}

The authors declare that there is no conflict of interest.

\section{FINANCIAL SUPPORT}

Secretaria de Ciência e Tecnologia do Estado do Pará, Ministério de Saúde do Brasil, UNESCO and Coordenação de Aperfeiçoamento Pessoal de Nivel Superior (CAPES). 


\section{REFERENCES}

1. World Health Organization: Status and Trends of STI, HIV/AIDS at the End of the Millennium, Geneva: World Health Organization; 1999.

2. Informes Técnicos Institucionais: Sífilis congênita e sífilis na gestação. Rev Saude Publica 2008; 42:768-772.

3. Ministério da Saúde. Boletim Epidemiológico - Aids e DST. Brasília: Ministério da Saúde; 2008.

4. Vaules MB, Ramin KD, Ramsey PS. Syphilis in pregnancy: A review. Microbes Infect 2002; 4:1133-1140.

5. Mandelbrot L, Marcollet A. Syphilis and pregnancy. Rev Prat 2004; 54:392-395.

6. Sheffield JS, Sanchez PJ, Wendel JR, Morris GD, Fong DWI, Margraf LR, et al. Congenital syphilis after maternal treatment for syphilis during pregnancy. Am J Obstet Gynecol 2002; 186:569-573.

7. Barbieri MA, Silva AM, Bettiol H. Risk factors for the increasing trend in low birth weight among live births born by vaginal delivery, Brazil. Rev Saude Publica 2000; 34:596-602.

8. LaFond RE, Lukehart AS. Biological basis for syphilis. Clin Microbiol Rev 2006; 19:29-49.

9. Mario SD, Say L, Lincetto O. Risk factors for stillbirth in developing countries: A systematic review of the literature. Sex Transm Dis 2007; 34 (supl 7):11-21.

10. Schmid G. Economic and programmatic aspects of congenital syphilis prevention. Bull World Health Organ 2004; 82:402-409.

11. Liu H, Bodes B, Chen CY, Steiner B. New tests for syphilis: Rational design of a PCR method for detection of Treponema pallidum in clinical specimens using unique regions of the DNA polymerase I gene. J Clin Microbiol 2001; 5:19411946.

12. Sutton MY, Liu H, Steiner B, Pillay A, Michey T, Finelli L, et al. Molecular subtyping of Treponema pallidum in an Arizona County with increasing syphilis morbidity: Use of specimens from ulcers and blood. J Infect Dis 2001; 83:16011606.

13. Marfin AA, Liu H, Sutton MY, Steiner B, Pillay A, Markowitz LE. Amplification of the DNA polymerase I gene of Treponema pallidum from whole blood of persons with syphilis. Diagn Microbiol Infect Dis 2001; 40:163-166.

14. Woznicová V, Votava M, Flasarová M. Clinical specimens for PCR detection of syphilis. Epidemiol Mikrobiol Imunol 2007; 56:66-71.

15. Pope V, Fox K, Liu H, Marfin AA, Leone P, Seña AC, et al. Molecular subtyping of Treponema pallidum from North and South Carolina. J Clin Microbiol 2005; 43:3743-3746.

16. Willis SG, Smith KS, Dunn VL, Gapter LA, Riviere KH, Riviere GR. Identification of seven Treponema species in health- and disease-associated dental plaque by nested-PCR. J Clin Microbiol 1999; 37:867-869.

17. Ayres M, Ayres MJ, Ayres DL, Santos AS. Bioestat 5.0. Aplicações estatísticas nas áreas das ciências biológicas e médicas. Sociedade Civil Mamirauá, Ministério da Ciência e Tecnologia (MCT). CNPq; 2007.

18. Pillay A, Liu H, Chen C, Hollaway B, Sturm AW, Steiner B, et al. Molecular subtyping of Treponema pallidum subspecies pallidum. Sex Trans Dis 1998; 25:408-414.

19. Palmer HM, Higgins SP, Herring AJ, Kingston MA. Use of PCR in the diagnosis of early syphilis in the United Kingdom. Sex Transm Infect 2003; 79:479-483.

20. Bruisten SM, Cairo I, Fennema H, Pijl A, Buimer M, Peerbooms PGH, et al. Diagnosing genital ulcer disease in a clinic for sexually transmitted diseases in Amsterdam, The Netherlands. J Clin Microbiol 2001;39:601-605.

21. Orle KA, Gates CA, Martin DH, Body BA, Weiss JB. Simultaneous PCR detection of Haemophilus ducreyi, Treponema pallidum and herpes simplex virus types 1 and 2 from genital ulcers. J Clin Microbiol 1996;34:49

22. Leslie DE, Azzato F, Karapanagiotidis T, Leydon J, Fyfe J. Development of real-time PCR assay to detect Treponema pallidum in clinical specimens and assessment of the assay's performance by comparison with serological testing. J Clin Microbiol 2007; 45:93-96.

23. Silleti RP. Comparison of CAPTIA Syphilis G Enzyme Immunoassay with Rapid Plasma Reagin Test for detection of syphilis. Clin Microbiol 1995 ;33:1829-1931
24. Geusau A, Kittler H, Hein U, Dangl-Erlach E, Stingel G, Tschschler E. Biological false-positive tests comprise a high proportion of Veneral Disease Research Laboratory reactions in an analysis of 300,000 sera. Int J STD AIDS 2005; $16: 722-726$

25. Larsen SA, Steiner BM, Rudolph AH. Laboratory diagnosis and interpretation of tests for syphilis. Clin Microbiol Rev 1995; 8:1-21

26. Bronzan RN, Mwesigwa-Kayongo DC, Narkunas D, Schmid GP, Neilsen GA, Ballard RC, et al. On-site rapid antenatal syphilis screening with an immunochromatographic strip improves case detection and treatment in rural South African clinics. Sex Transm Dis 2007; 34:55-60.

27. Ministério da Saúde. Diretrizes para o controle da sífilis congênita. Brasília: Ministério da Saúde; 2005.

28. Chakraborty R, Luck S. Syphilis is on the increase: the implications for child health. Arch Dis Child 2008; 93:105-109.

29. Woods CR. Syphilis in Children: Congenital and Acquired. Pediatr Infect Dis $2005 ; 16: 245-257$.

30. Funnyé AS, Akhtar AJ, Ven D. Syphilis and human immunodeficiency virus coinfection. J Natl Med Assoc 2003; 95:363-381.

31. Castro R, Prieto ES, Santo I, Azevedo J, Exposto FL. Detection of Treponema pallidum sp pallidum DNA in latent Syphilis. Int J STD AIDS 2007; 18: 842-845.

32. Duarte G, Gir E, Almeida AM, Hayashida M, Zanetti ML. Morte fetal por sífilis: avaliação epidemiológica realizada em Ribeirão Preto, Brasil. Bull Pan Am Health Organ $1994 ; 28: 42-49$.

33. Southwick KL, Blanco S, Santander A, Estenssoro M, Torrico F, Seoane G, et al Maternal and congenital syphilis in Bolivia, 1996: Prevalence and risk factors. Bull World Health Organ 2001; 79:33-42.

34. Conde-Agudelo A, Belizán JM, Diaz-Rossello JL. Epidemiology of fetal death in Latin America. Acta Obstet Gynecol Scand 2000; 79:371-378.

35. Schrag SJ, Arnold KE, Mohle-Boetani JC, Lynfield R, Zell ER, Stefonek K, et al. Prenatal screening for infectious diseases and opportunities for prevention. Obstet Gynecol 2003;102:753-760.

36. Serruya SJ, Cecatti JG, Lago TG. O Programa de humanização no pré-natal e nascimento do Ministério da Saúde no Brasil: Resultados iniciais. Cad Saude Publica 2004; 20:1281-1289.

37. Nascimento EMR, Costa MCN, Mota EL, Paim JS. Estudo de fatores de risco para óbito de menores de um ano mediante compartilhamento de banco de dados. Cad Saude Publica 2008; 24:2593-2602.

38. McDermott J, Steketee R, Larsen S, Wirima J. Syphilis-associated perinatal and infant mortality in rural Malawi. Bull World Health Organ 1993; 71:773-780.

39. Carey JC. Congenital syphilis in the $21^{\text {st }}$ century. Curr Women Health Rep 2003; 3:299-302.

40. Grimpel E, Sanchez PJ, Wendel GD, Burstain GH, McCracken JD, Radolf JD, et al. Use of polymerase chain reaction and rabbit infectivity testing to detect Treponema pallidum in amniotic fluid, fetal and neonatal sera, and cerebrospinal fluid. J Clin Microbiol 1991; 29:1711-1718.

41. Whicher K, Abbruscato F, Wicher V, Collins DN, Auger L, Horowitz HW. Identification of persistent infection in experimental syphilis by PCR. Infect and Immun 1998; 66:2509-2513. 